anus $^{22}$ del ya aludido fraile mercedario Juan Interián de Ayala, teólogo de la Universidad de Salamanca y miembro de la Real Academia Española, obra que será citada, volviendo a Italia, por el papa Benito XIV en un escrito dirigido al obispo de Augsburgo que puede ser considerado la primera monografía sobre la Trinidad en las artes visuales ${ }^{23}$.

En ninguno de los títulos arriba mencionados se hace alusión a las críticas que Diego de Cabranes realizó de las imágenes impropias en un contexto sagrado, especialmente la de la Trinidad con tres caras o cabezas. Sin embargo, y residiendo buena parte de su autoridad en los escritos de San Antonino, se adelantó el profesor salmantino a toda la ingente literatura postridentina, aunque su obra quedó prácticamente relegada al olvido...

Carlos Sastre VázQuez

\title{
A PROPÓSITO DEL BANCO DEL RETABLO DE SAN PELAYO, DEL MAESTRO DE BECERRIL
}

Después de desmontarse el retablo del Maestro de Becerril y de su posterior traslado a la catedral de Málaga desde Becerril de Campos ', Angulo citó el banco del retablo en la antigua colección Adanero de Madrid ${ }^{2}$. Al tratar del banco subraya cómo el pintor va renunciando a los fondos de oro berruguetescos ofreciendo más amplitud al paisaje y una sensibilidad estética más afín con Juan de Flandes.

Recientemente, debido a una publicación de quien escribe estas líneas referidas al banco ${ }^{3}$, los actuales propietarios me invitaron a estudiar y ver las tablas, que se hallan en perfecto estado de conservación, colgadas sin marco. Respecto a su estudio poco cabe añadir al entusiasmo demostrado por Angulo a propósito de las calidades de las indumentarias, joyería y paisaje, a cuyo juicio solo hay que añadir más énfasis respecto al espléndido colorido y serena elegancia de Salomón, Ezequiel, acompañado por Hércules y Sansón, en unos relieves del trono - Isaías y David.

Estas breves líneas sólo quieren dar a conocer la pervivencia de las tablas en la colección de los herederos de la antigua colección Adanero, en una época en que a causa del mercado de arte, las tablas circulan más de lo que sería deseable. Aunque la tablas se hallan en perfecto estado, las imágenes que reproducimos son del Archivo Fotográfico Moreno, en donde aparecen con marco y un número de identificación, constando en la antigua colección Adanero (págs. 1-4).

ISABEL MATEO Gómez

\footnotetext{
${ }^{22}$ Pictor christianus eruditus, sive de erroribus qui passim adminttuntur circa pingendas, atque effigendas Sacras Imagines, Madrid, 1730.

${ }^{23}$ F. Boespflug dedicó un ensayo a este documento: Dieu dans l'art. Sollicitudini Nostrae de Benoît XIV (1745) et l'affaire Crescence de Kaufbeuren, París, 1984. Como señaló G. Scavizzi, los problemas planteados a la Iglesia católica tras el cisma protestante fueron responsables de «la nascita dell'archeologia cristiana» («Storia ecclesiastica e arte nel secondo Cinquecento», Storia dell'arte, 59, 1987, 29-46, 38).

I I. Mateo Gómez y J. Mateo Viñes, La Celestina como fuente mitológica para el retablo de San Pelayo, del Maestro de Becerril, Archivo Español de Arte, 1999, p. 289-33.

2 D. Angulo, «Pintura del Renacimiento» en Ars Hispaniae, vol. XII, Madrid, 1954

${ }^{3}$ Catálogo Caylus, «De la Edad Media al Romanticismo», Madrid, 1992-93.
} 

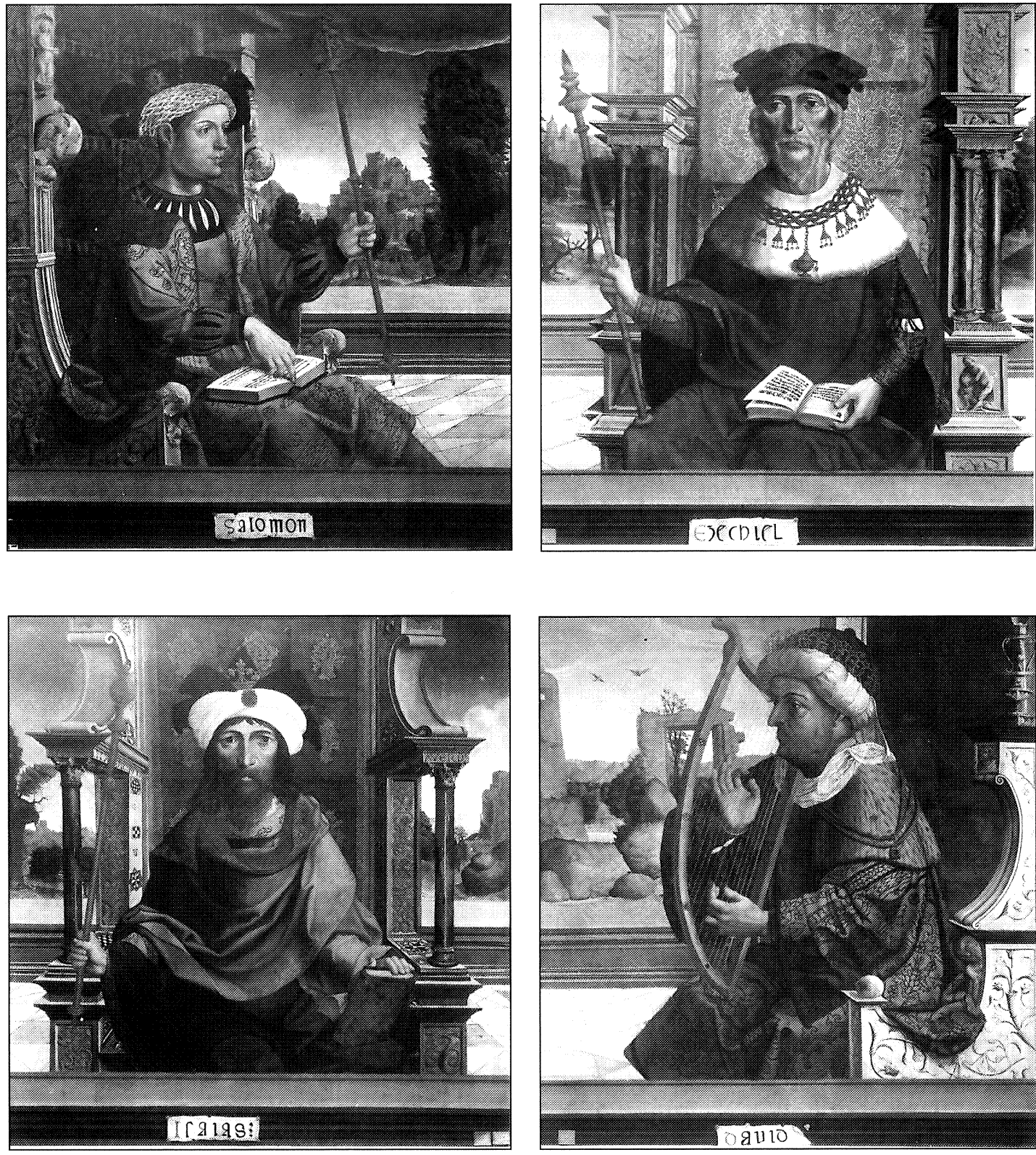

Figs. 1-4: Maestro de Becerril: Salomón, Ezequiel, Isaías y David. Banco del retablo de San Pelayo. Madrid. Colección privada. 